\title{
Koncepcja koprodukcji wiedzy a tworzenie polityki oparte na dowodach. Analiza literatury przedmiotu
}

\begin{abstract}
Streszczenie
W ostatnich latach pojęcie koprodukcji wiedzy zyskuje na znaczeniu. Wyrażenie to pozostaje jednak niejasne, podobnie jak jego związek z nurtem tworzenia polityki publicznej opartego na dowodach naukowych (evidence-based policy). Niniejszy artykuł, mający charakter przeglądowy, ma na celu przedstawienie, w jaki sposób, w wybranych publikacjach ważnych z punktu widzenia debaty naukowej na ten temat, rozumiana jest koprodukcja wiedzy. W tym - jak przedstawiane są role podmiotów uczestniczących w procesie koprodukcji wiedzy, a także jak kształtuje się związek między koprodukcją wiedzy a evidence-based policy. Analiza literatury umożliwia m.in. stwierdzenie, że koprodukcja wiedzy traktowana jest przez jej badaczy zarówno jako partycypacyjne podejście metodologiczne, jak i rozwiązanie instytucjonalne służące lepszej implementacji polityki.
\end{abstract}

Słowa kluczowe: koprodukcja, kokreacja, polityka publiczna, evidence-based policy Kody klasyfikacji JEL: H4, O30, D80, I29

\footnotetext{
1 Uniwersytet Warszawski, Wydział Nauk Politycznych i Studiów Międzynarodowych, Polska, e-mail: w.gedek@uw.edu.pl,https://orcid.org/0000-0003-4271-4485
} 


\title{
Knowledge co-production and the evidence-based policy: A literature review
}

\begin{abstract}
In the last couple of years, the concept of knowledge co-production has become more prominent. However, the meaning of the term and its relationship with the evidence-based policy (EBP) remains ambiguous. The main objectives of the review were to describe how the co-production of knowledge has been defined, the roles that individual actors can play in the process and the relationship between knowledge co-production and the evidence-based policy approach. The author asserted that the knowledge co-production was treated by the researchers both as a participatory research method and as an institutional solution for better policy implementation.
\end{abstract}

Keywords: co-production, co-creation, public policy, evidence-based policy

JEL Classification Codes: H4, O30, D80, I29

Tematyka koprodukcji wiedzy zyskuje na znaczeniu w anglojęzycznej debacie naukowej. Wyrazem tego jest fakt, że prestiżowe czasopismo Nature (2018) poświęciło temu zagadnieniu jedno ze swoich wydań specjalnych. Jednocześnie można zaobserwować brak publikacji na ten temat w polskim piśmiennictwie. Prezentowany w niniejszym artykule przegląd literatury ma służyć wypełnieniu tej luki. Jest on przy tym próbą umiejscowienia pojęcia koprodukcji wiedzy w ramach szerszego nurtu prac poświęconych tworzeniu polityki publicznej na podstawie dowodów naukowych (evidence-based policy - EBP). Pytanie badawcze, będące podstawą artykułu, dotyczy tego, jak rozumiana jest koprodukcja wiedzy. Ponadto autor stara się odpowiedzieć na pytania: Jak w literaturze przedmiotu charakteryzowane są role aktorów procesu koprodukcji wiedzy? Jak przedstawiana jest relacja między koncepcją EBP a koprodukcją wiedzy?

\section{Konteksty stosowania pojęcia koprodukcji}

Pojęcie koprodukcji zostało sformułowane po raz pierwszy w latach 70. XX w. przez zespół Ostrom z Uniwersytetu Indiany (Alford, 2013; Sześciło, 2015). Klasyczna definicja koprodukcji wskazuje, że jest to proces zaangażowania obywateli w świadczenie usług publicznych poprzez wzajemne interakcje obywateli z urzędnikami (Whitaker, 1980). Wpływ ten może mieć różnorodny charakter: od zwracania się 
obywateli o pomoc i wzajemne dostosowanie oczekiwań aż po podział wykonywanych działań między obywateli a administrację w zakresie świadczenia usług (Whitaker, 1980). Koprodukcja jest terminem obecnym w dyskursie naukowym także w Polsce (np. Pieliński, 2016; Ciepielewska-Kowalik, 2016; Kobylińska, 2018). Sześciło (2015) wyróżnił trzy filary, na których opiera się idea koprodukcji w administracji publicznej. Są to: partycypacja społeczna, wymieszanie zasobów publicznych i prywatnych, a także brak nastawienia na zysk ze strony uczestników.

Równolegle do badań koprodukcji w obszarze realizacji zadań publicznych rozwijały się nurty refleksji naukowej nad innymi rodzajami „współtworzenia”. Koprodukcja przyjmuje zatem odmienne znaczenia w zależności od kontekstu lub dyscypliny naukowej (Filipe, Renedo, Marston, 2017). Elementem, który łączy różne „koprodukcje”, jest postulat współtworzenia produktu, treści, polityki czy wiedzy przez uczestników tego procesu. W naukach społecznych można wyróżnić dwa teoretyczne konteksty posługiwania się pojęciem koprodukcji w odniesieniu do współtworzenia wiedzy naukowej. Pierwszy z nich związany jest z perspektywą socjologiczną w obszarze społecznych badań nad nauką i techniką rozwijaną przez Jasanoff (2004), czerpiącą m.in. z prac Latoura (2011). Zdaniem przywoływanej autorki dominujące dyskursy ekonomii, socjologii i nauk politycznych są pozbawione pojęć mogących trafnie oddać sposób, w jaki świat nauki łączy się z normami i hierarchiami społecznymi: „(...) społeczeństwo nie może funkcjonować bez wiedzy, tak jak wiedza nie może istnieć bez odpowiedniego społecznego wsparcia. Wiedza naukowa (...) zawiera w sobie i jest ugruntowana w ludzkich zwyczajach, tożsamościach, normach (...) i instytucjach - w skrócie we wszystkich elementach składających się na pojęcie »społeczny«. To samo, nawet w większym stopniu, dotyczy technologii” (Latour, 2011: 2-3, tłum. wł.).

Koprodukcja wiedzy jest praktyką, która w opinii Jasanoff (2004) podważa pozytywistyczne rozdzielenie sfer natury, faktów, obiektywnej rzeczywistości, tworzenia polityk (policy) od kultury, emocji społecznych i polityki (politics). Autorka podkreśla, że nauka i kultura kształtują się wzajemnie. W obszarze społecznych studiów nad nauką i techniką koprodukcja wiedzy jest zatem ramą interpretacyjną, która umożliwia umiejscowienie dowodów naukowych w ich społecznym kontekście (Jasanoff, 2004). Perspektywa ta uwzględnia analizę sposobów, w jakie dowody naukowe powstają i są wykorzystywane. Jasanoff zakłada, że nauka wpływa na zjawiska społeczne, a zjawiska społeczne na nią samą. Stąd próby sztucznego rozdzielenia sfer nauki i technologii z procesem demokratycznym są skazane na porażkę (Jasanoff, 2003).

Powyższe argumenty znalazły swój oddźwięk także w nauce o polityce publicznej sensu stricto (Karvonen, 2017). Część autorów opowiedziała się za stanowiskiem 
postulującym przeformułowanie sposobów wykorzystania dowodów naukowych w procesie tworzenia polityki publicznej tak, aby w większym stopniu uwzględniać partycypację społeczeństwa obywatelskiego (np. Nutley, Davies, Walter, 2003; Cairney, 2016; Parkhurst, 2017). Ostrza ich krytyki wymierzone były w paradygmat EBP, nurt zapoczątkowany w naukach medycznych jako medycyna oparta na dowodach (Parkhurst, 2017: 15), a następnie rozwijający się dynamicznie w nauce o polityce publicznej. Podstawami normatywnymi tego stanowiska są pozytywizm oraz próba naśladownictwa w naukach społecznych metodologii nauk biomedycznych.

Oponenci technokratyzmu, cechującego - zdaniem części autorów - EBP (Gilley, 2017), postulowali odrzucenie "naiwnego racjonalizmu” (Russel et al., 2008). Aprobatę zyskało stanowisko podkreślające, że w ramach procesu tworzenia polityki publicznej należy uwzględnić różnorodne wartości i postawy społeczne, a nie tylko wiedzę ekspercką (Cairney, 2016: 100, 128). W debacie o miejscu dowodów naukowych w polityce publicznej oznaczało to osłabienie pozycji technokratycznych na rzecz stanowisk odwołujących się do partycypacji obywatelskiej (jak Cairney, 2016; Parkhurst, 2017).

Drugim teoretycznym kontekstem dla rozważań na temat koprodukcji wiedzy $\mathrm{w}$ literaturze przedmiotu jest dyskusja na temat linearnego i interakcyjnego (Weiss, 1979; Nutley et al., 2010) modelu współpracy między naukowcami (wytwórcami wiedzy) a decydentami (i innymi użytkownikami wiedzy). Model linearny, od lat 90. XX w. utożsamiany z koncepcją transferu wiedzy (Mitton et al., 2007), zakłada jednostronność przekazywania wiedzy. Zgodnie z nim naukowcy informują polityków o wynikach badań, wpływając tym samym na decyzje polityczne. Badania na temat transferu wiedzy skupiają się na możliwych przeszkodach w przekazywaniu wiedzy decydentom politycznym (Newman et al., 2011): na przykład w postaci niedostosowania celów badań do oczekiwań decydentów albo problemów w komunikacji między tymi środowiskami.

Natomiast w modelu interakcyjnym, określanym również modelem wymiany wiedzy (knowledge exchange), podkreśla się rolę kontaktów między naukowcami, decydentami i innymi grupami interesariuszy. Jak ujmowała to Weiss: „Osoby zaangażowane $\mathrm{w}$ tworzenie polityki poszukują informacji nie tylko pochodzących od badaczy społecznych, a z różnych źródeł - od urzędników, polityków, praktyków, planistów, dziennikarzy, klientów, grup interesów, doradców, przyjaciół (...). Proces ten nie jest linearnym procesem przebiegającym od »badań « do »decyzji«, a niezorganizowanym zbiorem wzajemnych powiązań" (Weiss, 1979: 428, tłum. wł.).

Model ten zyskał współcześnie na znaczeniu pod wpływem rosnącej liczby dowodów wskazujących na to, że do skutecznego wykorzystania wiedzy naukowej $\mathrm{w}$ tworzeniu polityki silnie przyczyniają się relacje oparte na wzajemności między 
naukowcami a politykami (Mitton et al., 2007). Ponadto - zdaniem Włodarczyka: „To, co w uproszczonej wizji procesu decyzyjnego miało być jednorazowym aktem, jest w rzeczywistości złożonym, wewnętrznie skomplikowanym ciągiem wzajemnych interakcji” (Włodarczyk, 2010: 114). W konsekwencji w piśmiennictwie wzrasta zainteresowanie tymi aspektami współpracy między naukowcami a aktorami politycznymi, które służą zwiększeniu użyteczności wypracowywanej wiedzy naukowej (Geddes, Dommett, Prosser, 2017) i opierają się na dialogu jako formie: „zaangażowania potencjalnych użytkowników wiedzy we współtworzenie priorytetów badawczych" (Bennett, Jessani, 2011: 3-4, tłum. wł.).

Pojawienie się koncepcji koprodukcji wiedzy w nauce o polityce publicznej wpisuje się zatem w dwa zbliżone do siebie zjawiska w ramach debaty naukowej: afirmacji partycypacji obywatelskiej w procesie tworzenia polityki publicznej, formułowanej pod wpływem krytyk wymierzonych w stanowiska technokratyczne zbliżone do nurtu EBP, i pokrewnych dyskusji w obszarze science and technology studies (STS), jak również wzrostu znaczenia modelu interakcyjnego dla wyjaśniania skutecznego wykorzystywania wyników badań naukowych przez decydentów.

\section{Rysunek 1. Łączna liczba cytowań artykułów o koprodukcji wiedzy ( $w$ wybranych} naukach społecznych) w latach 2007-2019 $(\mathrm{N}=135)$

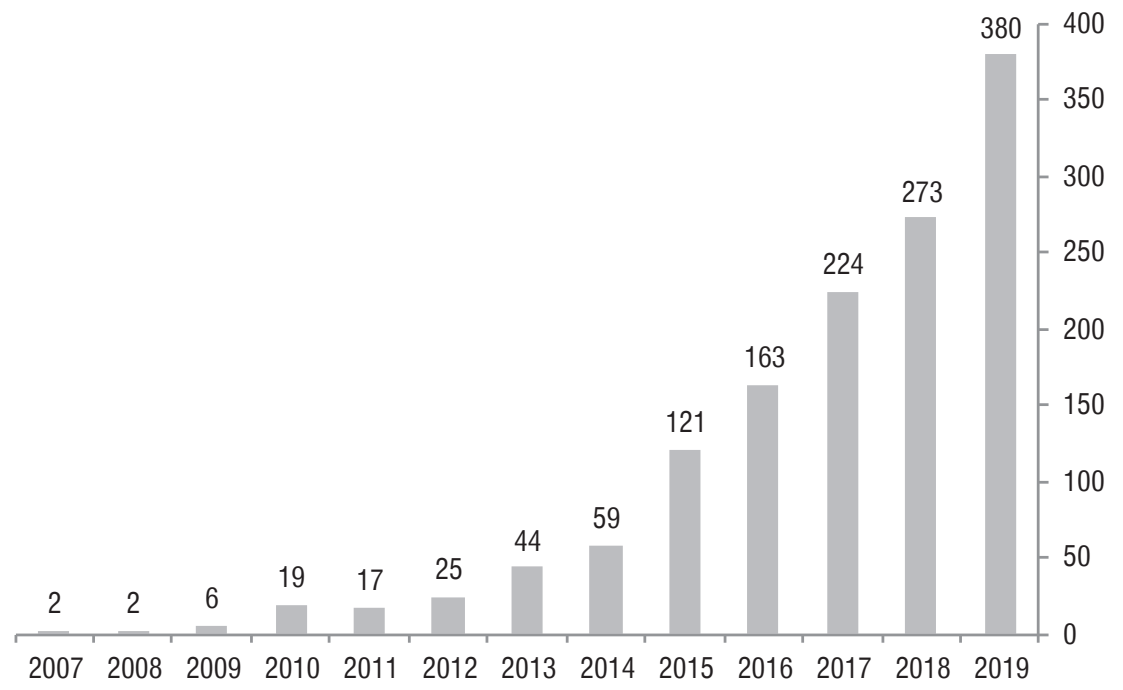

Źródło: opracowanie własne na podstawie danych z wyszukiwarki Web of Science (citation report).

Można zaobserwować wzrost naukowego zainteresowania problematyką koprodukcji wiedzy w naukach społecznych. Przejawem tego jest zwiększenie się liczby publikacji na ten temat i ich cytowań. Obrazują to przedstawione na rysunkach 1 i 2 
dane pochodzące z bazy Web of Science (serwer wydawcy, zob. Clarivate Analytics, 2019). Ukazują one łączną liczbę cytowań publikacji, w których używane jest pojęcie kluczowe knowledge co-production (koprodukcja wiedzy) w ramach wybranych nauk społecznych: socjologii, interdyscyplinarnych nauk społecznych, ekonomii, nauk politycznych oraz nauki o rozwoju (development studies) od 2007 do 2019 r. Wzrost ich liczby jest szczególnie widoczny od przełomu lat 2014-2015. Uzyskane wyniki wskazują na to, że jest to pojęcie stosunkowo nowe, jednak przebijające się w debacie naukowej. Rysunek 2 przedstawia procentowy udział publikacji zawierających odniesienia do pojęcia koprodukcji badań, w podziale na wybrane dyscypliny nauk społecznych. W uwzględnionym okresie dominowały artykuły w ramach socjologii i interdyscyplinarnych nauk społecznych.

Rysunek 2. Użycie pojęcia „koprodukcja wiedzy” w latach 2007-2019 w publikacjach naukowych $\mathrm{w}$ podziale na dyscypliny $(\mathrm{w} \%, \mathrm{~N}=135)$

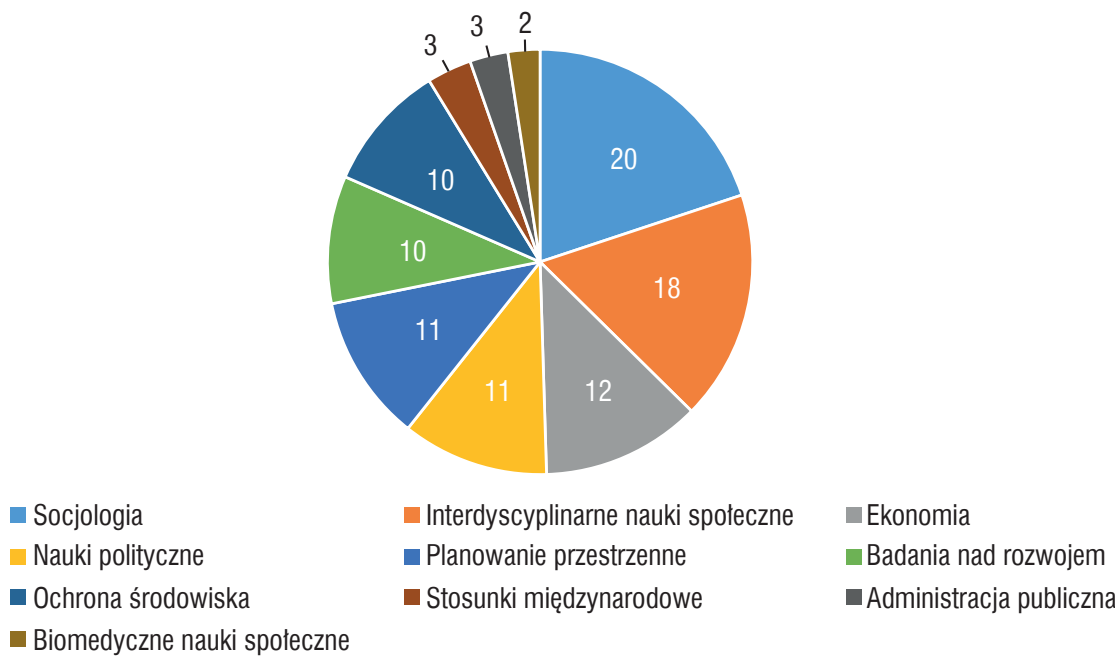

Źródło: opracowanie własne na podstawie danych z wyszukiwarki Web of Science (results analysis).

\section{Założenia analizy}

Udzieleniu odpowiedzi na postawione pytania badawcze służy metoda analizy literatury przedmiotu określana jako przegląd narracyjny. Technika ta jest szczególnie przydatna w przypadku prób uzupełnienia braków w dyskursie naukowym (Rozkwitalska, 2016; Green, Johnson, Adams, 2006). Przegląd narracyjny ma na celu zaznajomienie osób zainteresowanych z wybraną tematyką, nurtem myślenia, ewolucją 
znaczeń oraz ich krytyką (Zdonek, I., Hysa, Zdonek, D., 2016). Pozwala przy tym na krytyczną ewaluację i interpretację omawianych koncepcji (Rozkwitalska, 2016).

Analiza literatury oparta jest na dwustopniowym doborze źródeł. Po pierwsze, na podstawie kwerendy literatury przedmiotu dokonano celowego wyboru czasopisma Evidence \& Policy (w skrócie E\&P), które jest jednym z głównych periodyków koncentrujących się na teorii i praktyce relacji między badaniami naukowymi, wiedzą i polityką publiczną. Następnie wyselekcjonowano dziesięć artykułów naukowych, które zostały opublikowane w okresie ostatnich dziesięciu lat (2009-2019) w tym czasopiśmie. Od początku swojego istnienia periodyk ten był miejscem debat nad EBP. Jego redaktorem naczelnym w latach 2009-2017 był David Gough - wieloletni dyrektor EPPI-Centre, centrum badawczego będącego wpływowym ośrodkiem badań nad tą tematyką, funkcjonującego w ramach University College London.

Selekcji dziesięciu artykułów dokonano przy pomocy wyszukiwarki Web of Science. Wyszukiwanie artykułów oparto na użyciu słów kluczowych związanych z problematyką badawczą, takich jak: co-production, research and policy, co-creation. Wybór artykułów został ograniczony do badań poruszających tematykę koprodukcji wiedzy w kontekście tworzenia polityki, co oceniono na podstawie ich abstraktów. Za źródła dodatkowe, wybrane w kolejnym kroku procesu doboru źródeł, posłużyły publikacje spoza E\&P, ale istotne z punktu widzenia problematyki badawczej. Źródła te wykorzystano w celu rozwinięcia wątków zasygnalizowanych we wcześniej dobranych publikacjach. Dlatego, z nielicznymi wyjątkami, ich wyboru dokonano na podstawie bibliografii dziesięciu wcześniej wybranych artykułów².

\section{Definiowanie koprodukcji wiedzy}

Pojęcie koprodukcji wiedzy rozumiane jest jako współtworzenie wiedzy naukowej przez aktorów niebędących naukowcami (Geddes, Dommett, Prosser, 2017; Pohl et al., 2010). Co za tym idzie - w procesie koprodukcji wiedzy - wytwórcy i użytkownicy wiedzy to często te same osoby. Stąd, w analizowanych publikacjach, koprodukcja wiedzy jest określana również mianem koprodukcji badań naukowych (Geddes, Dommet, Prosser, 2017; Bammer, 2019). W tej konceptualizacji za głównych wytwórców wiedzy uważa się naukowców, a za jej użytkowników decydentów politycznych, osoby badane lub innych interesariuszy spoza społeczności akademickiej.

2 W przypadku tematyki badań partycypacyjnych i nauki obywatelskiej korzystano również z innych źródeł. W ich poszukiwaniu wykorzystano m.in. wyszukiwarkę Web of Science i CEJSH. 
Zaangażowanie w przebieg badania aktorów niebędących naukowcami jest w wielu dyscyplinach nauk społecznych aksjomatem. Przykładem podejścia koprodukcyjnego stosowanego w socjologii, antropologii, psychologii, pracy socjalnej czy naukach o zarządzaniu są partycypacyjne badania w działaniu (Participatory Action Research - PAR; Locock, Boaz, 2019), wywodzące się z myśli Lewina (Adelman, 1993; Sikora, 2013). Metoda ta opiera się na ciągłej refleksyjności działania oraz na badaniu „z ludźmi” zamiast „na ludziach” (Kafel, 2016). Oznacza to uznanie opinii osób badanych, współuczestniczących w tworzeniu badań, za kluczowe zarówno co do definiowania problemów badawczych, jak i przebiegu samego procesu badawczego. Jakkolwiek PAR jest klasyczną formą koprodukcji badań, za koprodukowane należy uznać wszystkie badania, które są współtworzone przez nienaukowców. Dotyczy to na przykład inicjatyw z zakresu nauki obywatelskiej (citizen science). Do nauki obywatelskiej zalicza się badania naukowe współtworzone z dużą liczbą naukowców-amatorów. Jednym z przykładów praktycznego zastosowania metody nauki obywatelskiej są badania migracji ptaków przy współudziale wolontariuszy pasjonatów korzystających z platformy internetowej eBird.org³, na której mogą się dzielić swoimi obserwacjami. W obywatelskich badaniach społecznych rola wolontariuszy wiąże się z procesem gromadzenia danych, czego przykładem może być określenie liczby napotykanych osób z interesującej naukowców grupy badanej (grupy jak np. osoby żebrzące; Purdam, 2014).

W analizowanych tekstach pojawiają się konkretne przykłady koprodukowanych badań. Należy do nich badanie zrealizowane przez zespół Sherriff (2019) - będące próbą budowy partnerstwa badawczego między naukowcami a rdzenną ludnością Australii. Zaangażowanie społeczności lokalnej w proces badawczy polegało na zastosowaniu metod zmierzających do dywersyfikacji źródeł wiedzy, tj. nie jednostronnego, lecz wzajemnego uczenia się badaczy i uczestników badań. Narzędziami wykorzystywanymi w tym celu były: zachęcenie do udziału w badaniu naukowców pochodzenia aborygeńskiego, spotkania o charakterze deliberatywnym zespołów zadaniowych złożonych z przedstawicieli obu grup, udział osób badanych w formułowaniu priorytetów badawczych, tworzeniu kwestionariuszy (by uwrażliwić je językowo stosownie do potrzeb społeczności) i negocjowanie sposobu ujęcia ostatecznych ustaleń zawartych w raporcie ze stroną badaną (Sherriff, 2019).

Analiza przedstawionego piśmiennictwa prowadzi jednak do wniosku, że definiowanie koprodukcji wiedzy jest utrudnione przez pewne niejasności co do znaczenia pojęcia oraz niekonsekwencje w jego stosowaniu w ramach dyscypliny (Nicholas et al., 2019), które odzwierciedlają problemy z ogólnym definiowaniem koprodukcji.

\footnotetext{
3 https://ebird.org/home (dostęp: 28.04.2020).
} 
Zjawiskiem występującym w omawianej literaturze jest zacieranie się granic między pojęciami takimi, jak: koprodukcja, kokreacja, współprojektowanie (co-design), badania partycypacyjne, które występują obok siebie, choć w dużej mierze się pokrywają (Locock, Boaz, 2019) ${ }^{4}$.

Przeanalizowane piśmiennictwo ujawnia także rozbieżność stanowisk na temat zakresu pojęcia koprodukcji wiedzy. Z jednej strony formułowany jest pogląd, zgodnie z którym koprodukcja wiedzy to podejście metodologiczne zacierające granice między wytwórcami a użytkownikami wiedzy (Geddes, Dommett, Prosser, 2017). Definicja ta umiejscawia koprodukcję wiedzy w modelu interakcyjnym relacji między podmiotami naukowymi a społecznymi. Określa koprodukcję jako formę współpracy i wpływu naukowców na rzeczywistość społeczną, a interesariuszy na proces badawczy (Geddes, Dommett, Prosser, 2017). Z drugiej strony część badaczy utożsamia koprodukcję wiedzy z ładem instytucjonalnym (Bekker et al., 2010).

Badacze, którzy traktują koprodukcję wiedzy jako podejście metodologiczne (Locock, Boaz, 2019; Pohl et al., 2010), odwołują się do typologii metod tworzenia wiedzy sformułowanej przez zespół Gibbonsa (1994) w książce The new production of knowledge: The dynamics of science and research in contemporary societies, w szczególności do podziału na pierwszy i drugi model tworzenia wiedzy (Mode 1 i Mode 2). Model 1 odpowiada badaniom konwencjonalnym metodologicznie, wywodzącym się wprost z ideałów pozytywistycznych. Zgodnie z tym podejściem badanie naukowe jest definiowane i w pełni kontrolowane przez naukowców, którzy zorganizowani są w dyscyplinach naukowych ze ściśle wytyczonymi granicami (Gibbons, 1994: 14-15). Wytwarzanie wiedzy podporządkowane jest społeczności akademickiej, która ma w tej kwestii swoisty monopol. Model 2, który zdaniem zespołu Gibbonsa współcześnie zyskał na znaczeniu w związku z rozpowszechnieniem się nowych technologii komunikacyjnych, zarezerwowany jest dla koprodukcyjnych form tworzenia wiedzy (Pohl et al., 2010). Charakteryzuje się on interakcyjnością, interdyscyplinarnością, nastawieniem praktycznym i ugruntowaniem wiedzy w konkretnych kontekstach (Gibbons et al., 1994: 14-15). W Modelu 2 naukowcy tracą swoją uprzywilejowaną pozycję w kwestii wytwarzania wiedzy, a z powodu zaangażowania w proces różnych aktorów społecznych zacierają się granice między społecznością akademicką a resztą aktorów społecznych biorących udział w wytwarzaniu wiedzy (Pohl et al., 2010) - np. publicystów, ekspertów pozauniwersyteckich, osób zaangażowanych w rzecznictwo, polityków, osób badanych itd. Co istotne, do modelu tego odwoływała się również Jasanoff (2003).

4 Mimo to właśnie „koprodukcja” jest pojęciem zdecydowanie najpopularniejszym (Durose et al., 2017). 
Ponieważ koprodukcja wiedzy wpisuje się w Model 2, charakteryzuje się elastycznością i refleksyjnością, które mogą być szczególnie przydatne w niekonwencjonalnych kontekstach badawczych, gdzie nie sprawdziłyby się tradycyjne metody, np. w pracy ze społecznościami pierwotnymi w kontekście postkolonialnym, jak w badaniu zespołu Sherriff (2019) koprodukowanego wraz z rdzennymi Australijczykami. Innym przykładem takiego kontekstu, opisanym przez zespół Geddesa (2017), jest funkcjonowanie instytucji publicznych. Przywoływany autor przeprowadził studium przypadku koprodukcji wiedzy między brytyjskimi naukowcami a pracownikami kancelaryjnymi brytyjskiego parlamentu, w efekcie czego stwierdził, że koprodukcja wiedzy jest najlepszym sposobem na zwiększenie wpływu badań naukowych na tworzenie polityki publicznej. Zespół kierowany przez Geddesa zwrócił szczególną uwagę na rolę sieci kontaktów między naukowcami a politykami, a także dostosowanie intensywności kontaktów i tematyki badań do agendy politycznej (Geddes, 2017). Zdaniem zespołu współtworzenie dowodów naukowych powinno uwzględniać czynniki takie jak okres wyborczy czy sytuacja polityczna, których znajomość umożliwia zaangażowanie w proces badawczy podmiotów o charakterze pozaakademickim.

Rozumienie koprodukcji jako zjawiska, które wykracza poza podejście metodologiczne, proponuje Bekker i jej zespół. Traktują oni koprodukcję jako jednoczesne wytwarzanie wiedzy i społecznego ładu (Bekker et al., 2010). Ich zdaniem proces ten rozgrywa się w ramach struktur współdzielonych przez twórców i użytkowników wiedzy. W przeciwieństwie do przedstawionego wcześniej stanowiska zrównującego koprodukcję z Modelem 2 tworzenia wiedzy naukowej w opisywanym podejściu koprodukcja wiedzy opiera się na tzw. instytucjach granicznych (boundry organisations), funkcjonujących na granicy między społecznością akademicką a aktorami pozaakademickimi (Pohl, 2010). Zgodnie z tym podejściem koprodukcja wiedzy nie musi oznaczać zacierania się granic między obiema grupami. Instytucje graniczne są miejscem, w którym spotykają się światy nauki i szeroko rozumianej polityki (Pohl, 2010). W opisywanym przez zespół Bekker przykładzie Holandii były to ciała doradcze (Advisory Councils on Research) przy instytucjach publicznych, w których oprócz ekspertów zasiadali przedstawiciele zorganizowanych grup interesu. Były to więc grona wyłonione $\mathrm{w}$ formule dialogu społecznego. W tej optyce koprodukcja wpisuje się w model demokracji konsensualnej, ponieważ w jej ramach aktorzy operują za kulisami konfliktu politycznego i wspólnie wypracowują wdrażane później rozwiązania (Bekker et al., 2010). Tak rozumiana koprodukcja wiedzy jest procesem zarówno wspólnego wytwarzania wiedzy (np. w formie raportów ciał doradczych z udziałem interesariuszy), jak i ukrytym elementem implementacji polityki (zachodzi w dużej mierze poza procesem legislacyjnym). Omawiane stanowisko wskazuje 
na możliwość istnienia „modeli” tworzenia wiedzy opartej na koprodukcji oraz ich zależności od lokalnej specyfiki instytucjonalnej.

Element, który łączy koncepcje koprodukcji wiedzy widoczne w przeanalizowanej literaturze, to interakcja między wytwórcami i użytkownikami wiedzy oparta na komunikacji i wspólnym zaangażowaniu. Przedstawione podejścia upodmiotowiają interesariuszy i użytkowników wiedzy (osoby niebędące częścią społeczności akademickiej) w ramach procesu współtworzenia wiedzy (Metz, Boaz, Robert, 2019; Yazejian et al., 2019). Odbywa się to w szczególności poprzez uwzględnienie wartości, opinii, stanowisk interesariuszy na różnych etapach procesu badawczego i relacji instytucjonalnych. Dzięki temu koprodukcja wiedzy może stanowić formę działania na rzecz osób w niej współuczestniczących (jak w przypadku koncepcji zespołu Sherriff). Koprodukcyjna budowa badania jest jednocześnie środkiem i celem koprodukcji wiedzy (Nicholas et al., 2019). Fundamentem tak rozumianego procesu jest niwelowanie nierówności między badaczami i uczestnikami badań czy też naukowcami i obywatelami, które wynikają z czynników instytucjonalnych (autorytet nauki), jak i strukturalnych (różnice klasowe, poziom kapitału kulturowego).

\section{Relacje i role aktorów w procesie koprodukcji wiedzy}

Zagadnieniem, któremu autorzy analizowanego piśmiennictwa poświęcają dużo uwagi, są relacje między uczestnikami procesu współtworzenia wiedzy. Znaczna część tych rozważań ma charakter empiryczny; autorzy starają się określić relacje między podmiotami, które przynoszą oczekiwane rezultaty. Zdaniem Bammer (2019) na koprodukcji w wymierny sposób mogą zyskiwać nie tylko interesariusze spoza świata naukowego (decydenci, osoby badane, osoby zaangażowane w projekt; Holmes, 2017), ale również naukowcy. Jak stwierdza: „Interesariusze mogą pomóc we współtworzeniu rozumienia problemu, jak również jego rozwiązań” (Holmes, 2017, tłum. wł.).

Aby osiągnąć tego typu zyski wynikające ze współpracy, potrzebne jest jednak jasne określenie ról. Zespół Geddesa (2017) podkreśla, że sposób zaangażowania interesariuszy zależy od konkretnej sytuacji badawczej; w niektórych kontekstach zaangażowanie w każdy z etapów badań będzie owocne, w innych pożądane jest włączenie zewnętrznych interesariuszy tylko na wybranych etapach procesu badawczego, takich jak definiowanie problematyki badawczej w formie wzajemnych konsultacji (mutual consultation). O znaczeniu współpracy wspomina również Metz ze współautorami: „Wzajemne konsultacje były opisywane jako działania promujące wytworzenie się wspólnego rozumienia przestrzeni problemu, biorące pod uwagę różne 
perspektywy, z zastosowaniem komunikacji, negocjacji, dostosowywania stanowisk i z wykorzystaniem stałych mechanizmów komunikacji dla promowania pozytywnych sprzężeń zwrotnych” (Metz, Boaz, Powell, 2019: 398, tłum. wł.).

Tabela 1. Uwarunkowania skutecznej koprodukcji wiedzy

\begin{tabular}{|c|c|c|}
\hline \multicolumn{3}{|c|}{ Czynniki wzmacniające proces koprodukcji wiedzy } \\
\hline Sherriff et al. (2019) & Yazejian et al. (2019) & Newman et al. (2011) \\
\hline $\begin{array}{l}\text { - Współdzielenie władzy w ramach } \\
\text { procesu } \\
\text { - Silne i wiarygodne przywództwo } \\
\text { - Wspólnie zdefiniowane cele } \\
\text { - Gotowość do podejmowania } \\
\text { ryzyka } \\
\text { - Budowanie porozumienia } \\
\text { międzykulturowego } \\
\text { - Upodmiotowienie społeczności } \\
\text { - Uszanowanie lokalnej wiedzy } \\
\text { nt. problemu badawczego } \\
\text { - Ciągłość kontaktów i inwestycji } \\
\text { w społeczność }\end{array}$ & $\begin{array}{l}\text { - Uwzględnianie różnic władzy } \\
\text { między aktorami } \\
\text { - Brokering/Mediacja } \\
\text { - Facylitacja } \\
\text { - Współtworzenie procesu } \\
\text { - Wspólne i wzajemne uczenie się } \\
\text { - Dostosowane wsparcie }\end{array}$ & $\begin{array}{l}\text { - Tworzenie relacji (wzajemność } \\
\text { relacji) } \\
\text { - Rozumienie różnic kulturowych } \\
\text { - Jasne stawianie celów } \\
\text { - Zdefiniowanie ról aktorów } \\
\text { - Współtworzenie procesu } \\
\text { i wyników procesu } \\
\text { - Tworzenie wniosków wynikających } \\
\text { z wiedzy }\end{array}$ \\
\hline
\end{tabular}

Źródło: opracowanie własne.

Wśród trzech spośród analizowanych artykułów - autorstwa zespołów Sherriff (2019), Yazejian (2019) i Newman (2011) - znajdują się opracowane na podstawie empirycznych studiów przypadku listy czynników, które poprawiają współpracę podmiotów w procesie koprodukcji wiedzy. Czynniki te zestawione są w tabeli 1. Jak widać, wiele z wymienionych cech się powtarza i odnosi się do wypracowywania partnerstwa między badaczami a pozaakademickimi interesariuszami. Podkreślana jest rola współtworzenia całego procesu badawczego, upodmiotowienia i elastyczności (tj. dostosowywania do kontekstu kulturowego). Koprodukcja wiedzy jest również wiązana $\mathrm{z}$ kategoriami takimi jak facylitacja. W rozumieniu zespołu Yazejian (2019) facylitacja to proces zachęcający do wspólnego rozwiązywania problemów ${ }^{5}$. Jest cyklem powtarzających się wzajemnych konsultacji aktorów procesu badawczego, pozwalających wykorzystać wiedzę wszystkich zainteresowanych stron i wzmocnić legitymizację procesu. Natomiast dostosowane wsparcie (tailored support) opiera się na rozumieniu procesu badawczego jako zależnego od kontekstu, celów czy też potrzeb zespołu badawczego i pozaakademickich uczestników badań (Yazejian et al., 2019). Cechą charakterystyczną koprodukcji wiedzy jest więc fakt, że

5 Pojęciu temu poświęcone jest przy tym piśmiennictwo nieodwołujące się bezpośrednio do kategorii koprodukcji wiedzy, m.in. z zakresu partycypacyjnych badań w działaniu, środowiskowej pracy socjalnej i aktywizowania społeczności lokalnej (por. Skrzypczak, 2014). 
natężenie i charakter interakcji między aktorami są przedmiotem powtarzających się negocjacji stron, wzajemnego dostosowywania się w zależności od dynamiki grupy i czynników zewnętrznych. Zaangażowanie interesariuszy i decydentów może być przy tym w wysokim stopniu zindywidualizowane, współpraca powinna mieć charakter dynamiczny i nielinearny (Bammer, 2019).

\section{Koprodukcja a tworzenie polityki oparte na dowodach naukowych (EBP)}

Na poziomie podstawowego celu, to znaczy zastosowania wysokiej jakości dowodów naukowych w procesie tworzenia polityki publicznej, nie ma sprzeczności między koprodukcją wiedzy a tworzeniem polityki opartym na dowodach. Kilku autorów omawianych artykułów bezpośrednio odwołuje się do tego nurtu (m.in. Yazejian et al., 2019; Bammer, 2019). Koprodukcja wiedzy może być wartościową formą tworzenia dowodów naukowych dostosowanych do konkretnych warunków społecznych, co widoczne było w szczegółowo opisanym przykładzie badania zespołu Sherriff (2019). W piśmiennictwie przedmiotu zdaje się dominować pogląd o tym, że dowody naukowe tworzone poza praktycznymi kontekstami są w niedostatecznym stopniu włączane do agendy politycznej (Yazejian et al., 2019). W praktyce oznacza to ograniczenie wpływu naukowców na tworzenie i implementację polityki publicznej, ponieważ dowody naukowe tworzone bez zwracania uwagi na potrzeby interesariuszy są słabiej wykorzystywane (Bammer, 2019). Koprodukcja wiedzy stanowi rozwiązanie tego problemu, ponieważ uwzględnienie wiedzy aktorów społecznych prowadzi do zwiększenia użyteczności wniosków procesu badawczego, a interakcje między naukowcami i nienaukowcami oparte na zasadzie wzajemności prowadzą do zwiększenia legitymizacji badań (Bammer, 2019).

Jakkolwiek w sferze podstawowych celów nie ma sprzeczności między koprodukcją wiedzy a paradygmatem EBP, to analiza omawianej literatury prowadzi do wniosku, że pewne sprzeczności ujawniają się w odniesieniu do metod preferowanych w obu tych podejściach. O ile bowiem w nurcie EBP prymat mają, zgodnie z tzw. hierarchią dowodów naukowych, systematyczne ilościowe przeglądy dowodów naukowych z randomizacją (Burns, Rohrich, Chung, 2011), to przykłady koprodukcji wiedzy prezentowane w wybranych artykułach dotyczą głównie badań o charakterze jakościowym. Zastosowanie metod ilościowych nie jest wprawdzie sprzeczne z podejściem koprodukcyjnym, takim jak partycypacyjne badania w działaniu (Sendall et al., 2018), jednak koprodukcja wiedzy pod postacią badań w działaniu trafia na podatniejszy grunt w przypadku metod jakościowych, w których kontakt 
z uczestnikami badań jest silnie wpisany w logikę procesu badawczego (np. Kafel, 2016). W dodatku koprodukcja wiedzy jest, w swoim aspekcie metodologicznym, koncepcją zbliżoną do ugruntowanego społecznie rzecznictwa, ponieważ dąży do upodmiotowienia uczestników procesu badawczego (jak w przypadku Sherriff et al., 2019), natomiast paradygmat tworzenia polityki opartego na dowodach cechuje się technokratyzmem (Gilley, 2017).

W wymiarze instytucjonalnym, zdaniem zespołu Bekker (2010), paradygmat EBP doprowadził w kontekście holenderskim, poprzez zwiększenie roli parametryzacji i komercjalizacji instytucji naukowych, do zmniejszenia roli koprodukcji wiedzy. Świadczy o tym m.in. marginalizacja i likwidacja science shops, działających przy uczelniach publicznych, określanych mianem „ludowych ośrodków badawczych", z których korzystały grupy interesariuszy lub nawet indywidualni obywatele (Bekker, 2010). Ich celem było tworzenie badań naukowych ściśle odpowiadających na potrzeby społeczne, w szczególności grup dotkniętych wykluczeniem (Wachelder, 2003). Grupy niemające środków, by opłacić przeprowadzenie prywatnych badań, jednak mogące zastosować ustalenia naukowe w praktyce - np. w rzecznictwie, mogły liczyć na wsparcie z ich strony.

$$
* * *
$$

Pojęcie koprodukcji wiedzy jest stosunkowo szeroko rozumiane w analizowanej literaturze przedmiotu. $\mathrm{W}$ omawianym piśmiennictwie dostrzec można różnorodność stanowisk odnoszących się do granic pojęcia, a także współwystępowanie terminów o podobnym znaczeniu (dotyczy to m.in. badań partycypacyjnych). Analiza zebranego materiału prowadzi do wniosku, że koprodukcja wiedzy jest definiowana dwojako: jako metoda badawcza zacierająca granice między wytwórcami a użytkownikami wiedzy (co jest spojrzeniem dominującym), a także jako zinstytucjonalizowana część procesu tworzenia polityki publicznej, który zachodzi w instytucjach współdzielonych przez przedstawicieli społeczności akademickiej i interesariuszy. Jako metoda badawcza, w świetle przedstawionej definicji, koprodukcja wiedzy obejmuje zarówno klasyczne badania partycypacyjne, jak i nowe podejścia badawcze, takie jak nauka obywatelska czy crowdsourcing. Taka konceptualizacja pojęcia koprodukcji wiedzy stanowi rozwiązanie problemu dualnego rozumienia pojęcia badań w działaniu, zasygnalizowanego w literaturze w polskim kontekście (Kafel, 2016 za: Ćwiklicki, Pawlina, 2015), w którym badania w działaniu (action research) są definiowane zarówno jako konkretna metoda badawcza, jak i zbiór wszystkich rodzajów badań w działaniu o charakterze partycypacyjnym.

Koprodukcja badań wpisuje się w Model 2 tworzenia wiedzy naukowej zaproponowany przez zespół Gibbonsa, a wzrost znaczenia tej koncepcji należy wiązać 
z krytycznymi dyskusjami wokół roli partycypacji obywatelskiej oraz roli interakcji w relacjach między naukowcami a interesariuszami (tj. z krytyką modelu linearnego). Przesłanką wyróżniającą koprodukcję wiedzy w każdej formie jest założenie o partnerstwie zaangażowanych stron. W analizowanych publikacjach wyróżniono czynniki, które wzmacniają proces koprodukcji wiedzy. Zaliczają się do nich wspólne zdefiniowanie problemów badawczych oraz minimalizowanie nierówności władzy między stronami. Tworzenie polityki publicznej na podstawie dowodów naukowych (EBP) i koprodukcja wiedzy mogą być przy tym komplementarnymi podejściami. Jest to jednak trudne, ponieważ podejście koprodukcyjne charakteryzuje się refleksyjnością i wrażliwością na nierówności władzy, a także jest powiązane z krytyką technokratyzmu i pozytywizmu metodologicznego.

Zaprezentowany przegląd piśmiennictwa przedstawia część obecnego stanu znajomości koprodukcji wiedzy. Należy spodziewać się wzrostu popularności omawianego tu pojęcia i dalszego rozwoju dyskusji wokół koprodukcji. Szczególnie w zakresie analizy empirycznej kontekstów koprodukcji wiedzy, jej zastosowań i ukrytych kosztów. Nie brakuje bowiem stanowisk krytycznie oceniających koprodukcję wiedzy. Oliver, Kothari i Mays (2019) argumentują: „Po pierwsze - istnieje bardzo mało dowodów empirycznych wskazujących na to, że badania kolaboracyjne prowadzą do poprawy wyników badań (...) Po drugie - badania kolaboracyjne niosą ze sobą poważne wyzwania (...) mogą być bardziej niepewne, wolniejsze i mniej innowacyjne od niekolaboracyjnych. Te wyzwania mogą być doświadczane przez cały proces badawczy" (tłum. wł.).

Wątpliwości wobec koprodukcji wiedzy powinny się stać podstawą kolejnych, bardziej rozbudowanych, dociekań naukowych dotyczących praktycznych aspektów procesu koprodukcji wiedzy w nowych kontekstach badawczych, a także w wymiarze instytucjonalnym.

\section{Bibliografia}

Adelman, C. (1993). Kurt Lewin and the Origins of Action Research. Educational Action Research, 1(1): 7-24.

Alford, J. (2013). The Multiple Facets of Co-Production: Building on the work of Elinor Ostrom. Public Management Review, 16(3): 299-316.

Bammer, G. (2019). Key issues in co-creation with stakeholders when research problems are complex. Evidence \& Policy, 15(3): 423-435.

Bekker, M., van Egmond, S., Wehrens, R., Putters, N., Bal, R. (2010). Linking research and policy in Dutch healthcare: infrastructure, innovations and impacts. Evidence \& Policy, 6(2): $237-253$. 
Bennett, G., Jessani, N. (eds.) (2011). The knowledge translation toolkit: Bridging the know-do gap: A resource for researchers. New Delhi: SAGE Publications India.

Burns, P.B., Rohrich, R.J., Chung, K.C. (2011). The levels of evidence and their role in evidence-based medicine. Plastic and Reconstructive Surgery, 128(1): 305-310.

Cairney, P. (2016). The Politics of Evidence-Based Policy-making. London: Palgrave Macmillan.

Ciepielewska-Kowalik, A. (2016). Koprodukcja w polityce opieki i edukacji przedszkolnej. Warszawa: Instytut Studiów Politycznych PAN.

Clarivate Analytics (2019). Journal Citation Reports: Journals Ranked by Impact: Social Science, Interdisciplinary. Web of Science, https://clarivate.com/webofsciencegroup/solutions/webof-science/ (dostęp: 28.04.2020).

Ćwiklicki, M. i Pawlina, A. (2015). Identyfikacja elementów metody action research w naukowym zarządzaniu. Organizacja i Kierowanie, 169(4): 55-69.

Durose, C., Needham, C., Mangan, C., Rees, J. (2017). Generating 'good enough' evidence for co-production. Evidence \& Policy, 13(1): 135-151.

Filipe, A., Renedo, A., Marston, C. (2017). The co-production of what? Knowledge, values, and social relations in health care. PLoS Biol., 15(5), https://doi.org/10.1371/journal.pbio.2001403

Gibbons, M., Limoges, C., Nowotny, H., Schwartzman, S., Scott, P., Trow, M. (1994). The new production of knowledge: the dynamics of science and research in contemporary societies. Los Angeles, CA, London, New Delhi: SAGE Publications.

Gilley, B. (2017). Technocracy and democracy as spheres of justice in public policy. Policy Sciences, 50(1): 9-22.

Geddes, M., Dommett, K., Prosser, B. (2017). A Recipe for Impact? Exploring knowledge requirements in the UK Parliament and beyond. Evidence \& Policy, 14(2): 259-276.

Green, B.N., Johnson, C.D., Adams, A. (2006). Writing narrative literature reviews for peerreviewed journals: secrets of the trade. Journal of Chiropractic Medicine, 5(3): 101-117.

Holmes, B.J. (2017). On the co-production of research: why we should say what we mean, mean what we say, and learn as we go. LSE Impact Blog, https://blogs.lse.ac.uk/impact ofsocialsciences/2017/09/21/on-the-co-production-of-research-why-we-should-say-whatwe-mean-mean-what-we-say-and-learn-as-we-go/ (dostęp: 28.04.2020).

Jasanoff, S. (2003). Technologies of Humility: Citizen Participation in Governing Science. Minerva, 41: 223-244.

Jasanoff, S. (2004). States of Knowledge: The co-production of science and the social order. Hoboken: Routledge.

Kafel, T. (2016). Zastosowanie metody participatory action research w diagnozowaniu organizacji pozarządowych. Zeszyty Naukowe UEK, 955(7): 23-40.

Karvonen, A. (2017). Book Review: The Politics of Evidence: From Evidence-Based Policy to the Good Governance of Evidence by Justin Parkhurst. LSE Review of Books, https:// blogs.lse.ac.uk/lsereviewofbooks/2017/07/12/book-review-the-politics-of-evidencefrom-evidence-based-policy-to-the-good-governance-of-evidence-by-justin-parkhurst/ (dostęp: 28.04.2020). 
Kobylińska, U. (2018). Koprodukcja usług publicznych w świetle przeglądu literatury. Zeszyt Naukowy Kolegium Zarządzania i Innowacji SGH, 162: 205-218.

Latour, B. (2011). Nigdy nie byliśmy nowocześni. Studium z antropologii symetrycznej. Warszawa: Oficyna Naukowa.

Locock, L., Boaz, A. (2019). Drawing straight lines along blurred boundaries: qualitative research, patient and public involvement in medical research, co-production and co-design. Evidence \& Policy, 15(3): 409-421.

Metz, A., Boaz, A., Powell, B.J. (2019). A research protocol for studying participatory processes in the use of evidence in child welfare systems. Evidence \& Policy, 15(3): 393-407.

Metz, A., Boaz, A., Robert, G. (2019). Co-creative approaches to knowledge production: what next for bridging the research to practice gap. Evidence \& Policy, 15(3): 331-337.

Mitton, C., Adair, C.E., McKenzie, E., Patten, S.B., Perry, B.W. (2007). Knowledge Transfer and Exchange: Review and Synthesis of the Literature. The Milbank Quarterly, 85(4): 729-768.

Nature (2018). The best research is produced when researchers and communities work together. Nature, 562.

Newman, L., Biedrzycki, K., Patterson, J., Baum, F. (2011). Partnership in knowledge creation: lessons learned from a researcher-policy actor partnership to co-produce a rapid appraisal case study of South Australia's Social Inclusion Initiative. Evidence \& Policy, 7(1): 79-98.

Nicholas, G., Foote, J., Kainz, K., Midgley, G., Prager, K., Zurbriggen, C. (2019). Towards a heart and soul for co-creative research practice: a systemic approach. Evidence \& Policy, 15(3): 353-370.

Nutley, S., Davies, H., Walter, I. (2003). Evidence-based policy and practice: cross-sector lessons from the United Kingdom. Social Policy Journal of New Zealand, 20: 29-48.

Nutley, S., Morton, S., Jung, T., Boaz, A. (2010). Evidence and Policy in Six European Countries: Diverse Approaches and Common Challenges. Evidence \& Policy, 6(2): 131-144.

Oliver, K., Kothari, A., Mays, N. (2019). Coming to terms with the hidden costs of co-production. LSE Impact Blog, https://blogs.lse.ac.uk/impactofsocialsciences/2019/06/19/coming-toterms-with-the-hidden-costs-of-co-production/ (dostęp: 28.04.2020).

Parkhurst, J. (2017). The politics of evidence, from evidence-based policy to good governance of evidence. Abingdon, OX: Taylor \& Francis.

Pieliński, B. (2016). Koprodukcja. W: W kręgu pojęć i zagadnień współczesnej polityki społecznej: B. Rysz-Kowalczyk, B. Szatur-Jaworska (red.): 169-178. Warszawa: Wyd. Uniwersytetu Warszawskiego.

Purdam, K. (2014). Citizen social science and citizen data? Methodological and ethical challenges for social research. Current Sociology, 62(3): 374-392.

Rozkwitalska, M. (2016). Efekt kraju pochodzenia a ocena kompetencji zawodowych obcokrajowców - przegląd narracyjny. Przedsiębiorczość i Zarządzanie, 17(2): 125-136.

Russel, J., Greenhalgh, T., Byrne, E., Mcdonnell, J. (2008). Recognizing Rhetoric in Health Care Policy Analysis. Journal of Health Services Research \& Policy, 13(1): 40-46. 
Sendall, M.C., McCosker, L.K., Brodie A., Hill, M., Crane, P. (2018). Participatory action research, mixed methods, and research teams: learning from philosophically juxtaposed methodologies for optimal research outcomes. BMC Medical Research Methodology, 18(1): 1-6.

Sherriff, S., Miller, H., Williamson, A., Tong, A., Muthayya, S., Redman, S., Bailey, S., Eades, S., Haynes, A. (2019). Building trust and sharing power for co-creation in Aboriginal health research: a stakeholder interview study. Evidence \& Policy, 15(3): 371-392.

Sikora, M. (2013). Małe przedmioty, duże historie - antropologiczne badania w działaniu. Tematy z Szewskiej, 2(10): 100-115.

Skrzypczak, B. (2014). W kierunku społecznościowej pracy socjalnej. Edukacyjno-środowiskowe determinanty interwencji publicznej. Warszawa: CAL.

Sześciło, D. (2015). Współzarządzanie jako koprodukcja usług publicznych. Zarządzanie Publiczne, 31(1): 13-21.

Wachelder, J. (2003). Democratizing science: various routes and visions of Dutch science shops. Science, Technology \& Human Values, 28(2): 244-273.

Weiss, C. (1979). The Many Meanings of Research Utilization. Public Administration Review, 39(5): 426-31.

Whitaker, G.P. (1980). Coproduction: Citizen Participation in Service Delivery. Public Administration Review, 40(3): 240-246.

Włodarczyk, C.W. (2010). Wprowadzenie do polityki zdrowotnej. Warszawa: Wolters Kluwer Polska.

Yazejian, N., Metz, A., Morgan, J., Louison, L., Bartley, L., Fleming, W.O., Haidar, L., Schroeder, J. (2019). Co-creative technical assistance: essential functions and interim outcomes. Evidence \& Policy, 15(3): 339-352.

Zdonek, I., Hysa, B., Zdonek, D. (2016). Publikacje przeglądowe w naukach o zarządzaniu - istota i tendencje. Zeszyty Naukowe Politechniki Śląskiej - Organizacja i Zarządzanie, 96: 519-533.

Unless stated otherwise, all the materials are available under the Creative

Commons Attribution 4.0 International license. Some rights reserved

to SGH Warsaw School of Economics.

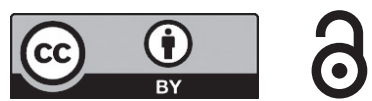

